\title{
Mucormycosis in Hematologic Malignancies: Clinical Follow-Up and Treatment Results
}

\author{
Hematolojik Malignitelerde Mukormikozis: Klinik Takip ve Tedavi Sonuçları
}

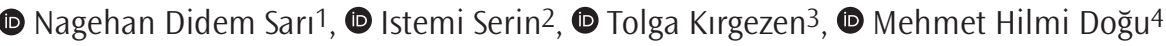 \\ 1University of Health Sciences Turkey, İstanbul Training and Research Hospital, Clinic of Infectious Diseases and Clinical Microbiology, istanbul, \\ Turkey \\ 2University of Health Sciences Turkey, İstanbul Training and Research Hospital, Clinic of Hematology, İstanbul, Turkey \\ 3University of Health Sciences Turkey, İstanbul Training and Research Hospital, Clinic of Otorlaryngology, İstanbul, Turkey \\ ${ }^{4}$ Istinye University, Liv Hospital Ulus, Department of Internal Medicine, İstanbul, Turkey
}

\begin{abstract}
Introduction: Mucormycosis is an aggressive-progressive invasive fungal infection caused by mold fungi in the division of mucorales of the zygomycetes class with high mortality, and is the most common fungal infection in patients with hematologic malignancies.

Methods: This study retrospectively evaluated patients with mucormycosis diagnosis between January 2015 and December 2019, including demographic features, hematologic diseases and comorbidities, radiological evaluations, symptoms and signs, treatments, and outcomes.

Results: Maxillofacial 9/19 (47.37\%) of patients and 10/19 (59.9\%) rhinoorbital mucor. Hematologic malignancy was observed in 15 (78.95\%) patients, whereas others had additional pre-disposing factors, such as diabetes mellitus and chronic renal failure. The most common find-ings were persistent fever, mucopurulent nasal flux, and periorbital edema. Endoscopic sinus surgery + medication was administered in 12/19 (62.2\%) patients and antifungal therapy in $7 / 19$ (37.8\%). In addition, 15/19 (79.95\%) patients died and 4/19 recovered with sequela.

Conclusion: The first large-scale mucormycosis study from our country will guide in determining the treatment algorithm. Effective and early surgery and antifungal application reduce mortality in mucormycosis by early diagnosis and multidisciplinary approach, without bone destruction in the paranasal sinus computed tomography with recurrent fever and earlystage sinusitis finding by performing a biopsy.

Keywords: Fungal infection, mucormycosis, hematology
\end{abstract}

\section{öz}

Amaç: Mukormikoz, yüksek mortaliteye sahip zigomiset sınıfının mucorales bölümünde yer alan, küf mantarlarının neden olduğu agresif ilerleyen invaziv bir mantar enfeksiyonudur. Hematolojik maligniteli hastalarda en sık görülen mantar enfeksiyonu olarak karșımıza çıkmaktadır.

Yöntemler: Çalışmamızda Ocak 2015-Aralık 2019 tarihleri arasında mukormikoz tanısı alan hastalar retrospektif olarak değerlendirildi. Hastaların demografik özellikleri, hematolojik hastalıkları ve komorbiditeleri, radyolojik değerlendirmeleri, semptom ve bulguları, tedavileri ve sonuçları değerlendirildi.

Bulgular: Olgularımı 9/19 $(\% 47,37)$ maksillofasiyal ve 10/19 $(\% 59,9)$ rinoorbital mukor hastalarıydı. Hastaların 15'inde $(\% 78,95)$ sadece hematolojik malignite varken, diğerlerinde diabetes mellitus ve kronik böbrek yetmezliği gibi ek predispozan faktörler vardı. En sık görülen bulgular inatçı ateş, mukopürülan burun akısı ve periorbital ödemdi. Hastaların $12 / 19$ 'u $(\% 62,2)$ endoskopik sinüs cerrahisi + antifungal tedavi ve $7 / 19$ 'u $(\% 37,8)$ sadece antifungal tedavi gördü. Hastaların 15/19’u $(\% 79,95)$ öldü ve bunların 4/19'u sekel ile iyilești.

Sonuç: Ülkemizden ilk büyük ölçekli mukormikoz çalıșması, tedavi algoritmasının belirlenmesi açısından yol gösterici olacaktır. Erken tanı ve multidisipliner yaklaşımla, etkili ve erken cerrahi ve antifungal uygulama ve biyopsi ile, mukormikozda mortalitenin, tekrarlayan ateş ile paranazal sinüs bilgisayarlı tomografide kemik destrüksiyonu olmaksızın, azaltılabileceğini düșünmekteyiz.

Keywords: Fungal enfeksiyon, mukormikoz, hematoloji

\section{Introduction}

Mucormycosis is an aggressive-progressive invasive fungal infection caused by mold fungi in the division of mucorales of the zygomycetes class (1,2), which is the most common fungal infection after Aspergillus spp. in patients with stem cell and solid organ transplantation $(3,4)$. The true incidence of the disease is unknown; however, its incidence in the United States is 1.7/1000000 per year with approximately 500 cases per year (5). The incidence of autopsies performed in the risky patient
Address for Correspondence/Yazıșma Adresi: Istemi Serin MD, University of Health Sciences Turkey, İstanbul Training and Research Hospital, Clinic of Hematology, İstanbul, Turkey

Phone: +90 2125829868 E-mail: serinistemi@hotmail.com ORCID ID: orcid.org/0000-0003-1855-774X

Cite this article as/Atıf: Sarı ND, Serin I, Kırgezen T, Doğu MH. Mucormycosis in Hematologic Malignancies: Clinical Follow-Up and Treatment Results. İstanbul Med J 2021; 22(4): 245-9.

(c) Copyright 2021 by the University of Health Sciences Turkey, Istanbul Training and Research Hospital/istanbul Medical Journal published by Galenos Publishing House.

(C) Telif Hakkı 2021 Sağıı Bilimleri Üniversitesi Istanbul Ĕgitim ve Araştırma Hastanesi/Istanbul Tıp Dergisi, Galenos Yayınevi tarafından basılmıștır.

Received/Geliș Tarihi: 02.02.2021 Accepted/Kabul Tarihi: 21.06.2021 
group was $8-13 \%$, as it is responsible for $10 \%$ of the invasive mold-fungal infections in the high-risk patient group $(6,7)$.

Disease prevalence is high in patients with uncontrolled diabetes mellitus (DM), especially in undeveloped countries; however, it was reported in patients with hematologic malignancy and organ transplantation $(8,9)$. In recent years, mucormycosis cases were reported under posaconazole prophylaxis, and was published that voriconazole prophylaxis causes a mucormycosis predisposition (10-13).

Turkey has very few numbers of reported mucormycosis incidences and publications with hematologic malignancy at the level of case reports, without case series. This study aimed to retrospectively evaluate patients with hematologic malignancies and mucormycosis, who were followed and treated in our hospital.

\section{Methods}

Our single-center retrospective study examined mucormycosis cases over the age of 18 years with hematologic malignancy between January 2015 and December 2019 with the approval of the University of Health Sciences Turkey, İstanbul Training and Research Hospital Ethical Committee (approval number: 2204, date: 21.02.2020). Informed consent was obtained from all participants. The diagnosis was made based on the European Organization for Research and Treatment of Cancer/Mycoses Study Group (EORTC/MSG) (14) diagnostic criteria. Demographic features, additional comorbidities, laboratory, clinical, and treatment results of the cases were evaluated through the hospital registration system.

\section{Statistical Analysis}

This study contains descriptive data of the patient group. STATA software version 12.0 was used to analyze patient data. Data results were given as mean, standard deviation, or median and interquartile range according to their suitability. Informed consent was obtained from patients for clinical information and result utilization.

\section{Results}

Out of 19 patients who met the study criteria, 12 were female and 7 were male, and the median age was 58 years (range: 23-84). Apart from hematologic malignancy, predisposing conditions were determined as DM, chelation therapy (using deferoxamine), and additional immunosuppressive therapy. According to the EORTC/MSG criteria, 12/19 (63.16\%) were evaluated as definite and 7/19 (36.84\%) were possible mucormycosis. The cases had hematologic malignancy in $12 / 19$ (63.16\%) and multiple predisposing factors in 7/19 (36.85\%). Case diagnoses were evaluated as follows: Acute myeloid leukemia (AML) $(n=6)$, myelodysplastic syndrome (MDS) $(n=6)$, acute lymphocytic leukemia $(n=4)$, and lymphoma $(n=3)$.

Paranasal sinus computed tomography (CT), which was the first choice in radiological imaging, was evaluated as rhinosinusal (RS) with isolated sinus involvement and rhinoorbital (RO) with orbital involvement. RO was classified in 9/19 (42.1\%) of cases and RS in 10/19 (57.9\%). In addition to the cases evaluated as RO $(n=10)$, orbital magnetic resonance imaging (MRI) was performed. Of these cases, $62.2 \%$ were operated on and histopathologically confirmed. The demographic and clinical characteristics of the cases were evaluated in the study as presented in Table 1. The most common symptoms and signs was high fever in 17 patients (89.47\%), mucopurulent nasal discharge in 15 patients (78.95\%), percent sensitivity in $12(63.16 \%)$, periorbital edema in 11 (57.90\%), redness in $9(47.37 \%)$, paralysis in $8(42.11 \%)$, palate necrosis in 5 (26.32\%), proptosis (21.05\%) in 4, and exophthalmos (15.79\%) in 3.

Our study calculated the annual disease incidence over 10000 applications/year and is 0.02-0.3/10000 between 2015 and 2019, as shared in Figure 1.

Mycological cultures were made in 7 cases, but in 2 Mucor spp. reproduction was detected, without possible typing. However, histopathological confirmation was provided in all patients who are operated on.

Considering the most common symptoms and signs, 17 patients (89.47\%) had a high fever, 15 (78.95\%) had mucopurulent nasal discharge, 12 (63.16\%) had face sensitivity, 11 (57.90\%) had periorbital edema, 9

Table 1. Demographic characteristics, clinical forms, hematologic diseases, and therapeutic outcomes of patients

\begin{tabular}{|c|c|}
\hline & n (\%) \\
\hline Age, median (range) & $58(23-84)$ \\
\hline Genter (male/female) & $7 / 12$ \\
\hline \multicolumn{2}{|l|}{ Hemotologic diseases/comorbidities } \\
\hline AML & $5(26.32)$ \\
\hline ALL & $4(33.33)$ \\
\hline Lymphoma & $2(10.53)$ \\
\hline AA & $2(10.53)$ \\
\hline MDS & $2(10.53)$ \\
\hline $\mathrm{MM}+\mathrm{DM}^{*}+\mathrm{CRF}^{*}$ & $1(5.26)$ \\
\hline $\mathrm{AML}+\mathrm{DM}^{*}$ & $1(5.26)$ \\
\hline $\mathrm{MDS}+\mathrm{DM}^{*}+\mathrm{CRF}^{*}$ & $2(10.53)$ \\
\hline Antifungal use & $11(57.89)$ \\
\hline Fluconazole & $4(33.33)$ \\
\hline Posaconazole & $3(15.79)$ \\
\hline Voriconazole & $4(33.33)$ \\
\hline \multicolumn{2}{|l|}{ Anatomical localization } \\
\hline Maxillofacial & $9(42.1)$ \\
\hline Rhinoorbital & $10(57.9)$ \\
\hline \multicolumn{2}{|l|}{ Treatment } \\
\hline Endoscopic sinus surgery + medication & $12(62.2)$ \\
\hline Only medication & $7(37.8)$ \\
\hline \multicolumn{2}{|l|}{ Outcome } \\
\hline Death & $15(79.95)$ \\
\hline Mucor & $12(63.15)$ \\
\hline Myocardial infarction & $2(10.53)$ \\
\hline Hemorrhage & $1(5.26)$ \\
\hline Recovery & $4(33.33)$ \\
\hline
\end{tabular}


(47.37\%) had redness, 8 (42.11\%) had paralysis, 5 (26.32\%) had palate necrosis, 4 (21.05\%) had proptosis, and 3 (15.79\%) had exophthalmos. Symptoms and findings of patients are demonstrated in Table 2.

Posaconazole prophylaxis was given to $3 / 19$ (15.79\%) cases, whereas 4/19 (21.05\%) were taking voriconazole $2 \times 4 \mathrm{mg} / \mathrm{kg} /$ day with highpossible invasive fungal infection. Liposomal amphotericin B (L-AMB) $1 \times 5-6 \mathrm{mg} / \mathrm{kg} /$ day was administered to all patients diagnosed with mucor and 2 patients, without previously posaconazole prophylaxis treatment, received posaconazole and L-AMB combination therapy. The mean anti-fungal application time was 55.63 (3-260) days, 102.5 (20-260) days for survivors, 49.27 (3-100) for non-survivors. Posaconazole and L-AMB combination was administered in 2 of the surviving cases. The overall mortality rate was $79.95 \%$ and mortality attributed to mucor was $63.15 \%$ (3 patients died due to different reasons).

\section{Discussion}

Mucormycosis is an angioinvasive fungal infection with hematologic malignancy, especially in patients receiving chemotherapy and/ or immunosuppressive therapy, causing sudden onset and high mortality. The causative spores of fungi are found mostly in soil, rotten fruits and vegetables, and moldy foods. Spores settle on the sinuses through inhalation or on the mucous membrane by contact cause invasion, vascular occlusion, and diffuse tissue necrosis in the vascular endothelium in cases with dysfunctional phagocytosis and neutrophil functions. Host defense determines the disease spread;

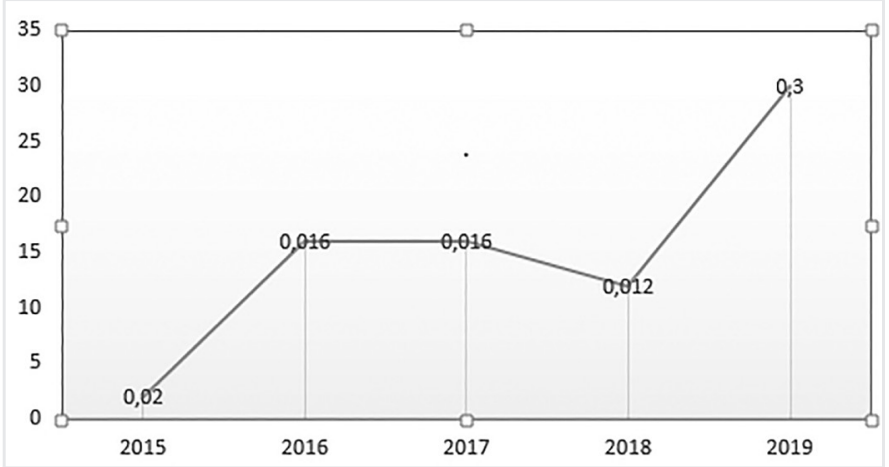

Figure 1. 10000 applications/year incidence between 2015 and 2019

*Demonstrates the change in the incidence of mucormycosis in patients diagnosed with hematological malignancies in our center between 2015 and 2019

Table 2. Symptoms and findings of patients

Symptoms/findings $\mathbf{n}(\%)$

Fever 17 (89.47)

Mucopurulent discharge 15 (78.95)

Facial sensitivity 12 (63.16)

Periorbital edema 11 (57.90)

Redness 9 (47.37)

Paralysis 8 (42.11)

Palate necrosis 5 (26.32)

Propitozis 4 (21.05)

Exophthalmos 3 (15.79) therefore, in addition to hematologic malignancy, they are at high risk situations due to the following: diabetic ketoacidosis, intense and longterm corticosteroid use, premature birth, human immune deficiency virus, and patients who underwent solid organ transplantation. Therefore, despite the systemic antifungal usage and aggressive surgical debridement, mortality is very high (15-17), which was rarely reported in healthy people after iatrogenic injuries and after natural disasters such as volcano eruption and proboscis (18-21).

Its clinical course was known for a long time; however, its epidemiology remains undetermined. Patients with hematological malignancy and organ transplantation are at the forefront in developed countries; however, uncontrolled DM ranks first in developing countries, such as Iran and India (8,22-25). A study from Turkey by Kursun et al. (26) determined DM as 50\% and hematologic malignancy as $18 \%$ in series of 28 cases. The study of Arda et al. (27) reported hematologic malignancies as $50 \%$ and DM as $25 \%$. A meta-analysis that included 851 cases by Jeong et al. (28) revealed that DM was $40 \%$, hematological malignancy was $33 \%$, and organ transplantation was $14 \%$ as predisposing.

The annual incidence was $0.47 / 10000$ in the study from Lebanon; however, another study for DM was reported as 10.31/10000 $(29,30)$, whereas Our study calculated the annual incidence as $0.073 / 10000$ years for patients with hematological malignancies (Figure 1).

The annual incidence was $0.47 / 10000$ in the study from Lebanon, with DM as $10.31 / 10000$, whereas our study calculated it as $0.073 / 10000$ per year for patients with DM.

The definitive diagnosis is made by histopathological examination; however, imaging methods help determine the invasion and complications rather than the disease diagnosis. CT demonstrated bone destruction and MRI provides more information in the intracranial and orbital structure invasion evaluation (31). McDonogh et al. (32) emphasize the need to suspect mucormycosis when symptoms of sinusitis are seen clinically and radiologically in patients with immune deficiency or DM. Mucosal sinus CT should be taken in all our patients to detect mucosal thickening in the early stages. Bone destruction is an early sign for mucor $(n=10)$, thus an orbital and facial MRI was taken to determine the orbital spread. RO was observed in 9/19 (42.1\%) cases and RS in 10/19 (57.9\%).

Mucormycosis begins with necrosis in the palate or sinuses reaching the orbital and brain tissues (33). Patients usually present with facial paralysis and headache, fever, and signs related to soft tissue inflammations. Depending on the necrosis, black creams on the palate and nose are observed. Symptoms and findings detected in our study were resistant fever (89.47\%), mucopurulent nasal discharge (78.95\%), and facial area pain (67.2\%) in both groups. Palate necrosis was seen in $26.32 \%$ in RS localization, neurological symptoms were seen in RO localization; paralysis in $47.37 \%$, proptosis in $21.05 \%$, and exophthalmos in $15.79 \%$.

For a definitive diagnosis, a deep biopsy sample is taken from the suspicious nasal and/or oral mucosal lesions and fresh tissue samples are examined by histopathological and microbiological methods; septumfree, randomly-branching hyphae should be seen and macroscopic and 
microscopic examination of colonies that were grown in Sabouraud dextrose agar media should be done (34). The review of Jeong et al. (28) achieved a histopathological diagnosis of $88 \%$.

The underlying disease must be corrected to use systemic antifungal therapy in mucormycosis treatment, removal of necrotic tissues due to invasion and thrombosis, and host defense recovery. Operation decision in patients with hematologic malignancy becomes difficult due to factors, such as thrombocytopenia, anemia, and coagulation pathologies. Therefore, earlier antifungal therapy initiation is vital. A study by Chamilos et al. (35) retrospectively evaluated 70 patients with hematologic malignancies, which revealed a two-fold increase in mortality 12 weeks after diagnosis in patients in which anti-fungal therapy was started after the $6^{\text {th }}$ day following the mucor diagnosis. In our study, all patients received L-AMB after a paranasal sinus CT. The average time of operation of patients was 4.4 (1-15) days after CT.

Statistical comparison was not made due to a small case group. Our overall mortality rate was 15/19 (79.95\%); however, three of our cases died due to non-mucormycosis reasons. Mortality attributed to mucor was calculated as $63.15 \%$. According to published studies, the mortality rate varies between $30 \%$ and $69 \%$. The survivor evaluation revealed that most of them were RS located, with the time of operation at 2.2 (1-18) days after the paranasal sinus $C T$, and the average duration of antifungal therapy was 102.5 (90-120) days. Survivors used 62.8\% (35-92) L-AMB and were cured with a posaconazole (800 mg PO/day) tablet within 172.6 (75-354) days.

Posaconazole is an azole with anti-mucor activity. Suspension form absorption is directly related to food and its consumption is recommended with a fatty or high-calorie meal. In our country, the first approved suspension form for invasive fungal infection prophylaxis during MDS and AML induction therapy was firstly used in our cases. In our series $(n=5)$, patients who developed mucor under prophylaxis (15.79\%) were using posaconazole (3x200 mg/day), but three of these cases were used for $<10$ days.

This retrospectively planned study was unable to evaluate the effective dose at a blood concentration level of the drug. Different studies reported that breakthrough infections develop under posaconazole prophylaxis and inappropriate usage of the recommended prophylactic medication (36-38). Posaconazole tablet was used after discharge in patients using L-AMB at the hospital. Posaconazole tablets were preferred due to their high efficacy, good tolerability, and low drug interaction.

\section{Study Limitations}

The most important limitation of the study was the small patient group. The difference in the time to surgery was an important obstacle to make a comparison between patients.

\section{Conclusion}

In our country, published case-based reports are limited and we believe that it is the first large-scale mucormycosis study conducted in a group of patients with hematologic malignancies, which will shed light on the future treatment algorithm determination. In this study, effective surgery and antifungal application reduce mucormycosis mortality by performing an early diagnosis with a multidisciplinary approach and biopsy sampling with persistent fever before bone destruction in the paranasal sinus CT and before further development.

Acknowledgments: We respectfully remember all the colleagues we lost in the COVID-19 fight.

Ethics Committee Approval: This study was approved by the Ethics Committee of the University of Health Sciences Turkey, İstanbul Training and Research Hospital (approval number: 2204, date: 21.02.2020).

Informed Consent: Informed consent was obtained from all participants.

Peer-review: Externally and internally peer-reviewed.

Authorship Contributions: Surgical and Medical Practices - T.K., Concept - N.D.S., T.K.; Design - N.D.S., I.S.; Data Collection or Processing - N.D.S., T.K.; Analysis or Interpretation - I.S.; Literature Search - N.D.S., M.H.D.; Writing - M.H.D, I.S.

Conflict of Interest: No conflict of interest was declared by the authors

Financial Disclosure: The authors declared that this study received no financial support.

\section{References}

1. Bouza E, Muñoz P, J Guinea J. Mucormycosis: an emerging disease? Clinical Microbiology and Infection 2006; 12(Suppl7): 7-23.

2. Kontoyiannis DP, Lewis RE, Lortholary O, Spellberg B, Petrikkos G, Roilides E, et al. Future directions in mucormycosis research. Clin Infect Dis 2012; 54(Suppl1): S79-85.

3. Slavin M, van Hal S, Sorrell TC, Lee A, Marriott DJ, Daveson K, et al.; Australia and New Zealand Mycoses Interest Group. Invasive infections due to filamentous fungi other than Aspergillus: epidemiology and determinants of mortality. Clin Microbiol Infect 2015; 21: 490.e1-10.

4. Park BJ, Pappas PG, Wannemuehler KA, Alexander BD, Anaissie EJ, Andes DR, et al. Invasive non-Aspergillus mold infections in transplant recipients, United States, 2001-2006. Emerg Infect Dis 2011; 17: 1855-64.

5. Kontoyiannis DP, Lewis RE. Agents of mucormycosis and Entomophthoramycosis, Mandell GL, Bennett GE, Dolin R, eds. Mandell, Douglas and Bennett's Principles and Practice of Infectious Diseases. Philadelphia, Pa: Churchill Livingstone. 2010; p. 3257-69.

6. Abidi MZ, Sohail MR, Cummins N, Wilhelm M, Wengenack N, Brumble L, et al. Stability in the cumulative incidence, severity and mortality of 101 cases of invasive mucormycosis in high-risk patients from 1995 to 2011: a comparison of eras immediately before and after the availability of voriconazole and echinocandin-amphotericin combination therapies. Mycoses 2014; 57: 68798.

7. Kume H, Yamazaki T, Abe M, Tanuma H, Okudaira M, Okayasu I. Increase in aspergillosis and severe mycotic infection in patients with leukemia and MDS: comparison of the data from the Annual of the Pathological Autopsy Cases in Japan in 1989, 1993 and 1997. Pathol Int 2003; 53: 744-50.

8. Skiada A, Pagano L, Groll A, Zimmerli S, Dupont B, Lagrou K, et al.; European Confederation of Medical Mycology Working Group on Zygomycosis. Zygomycosis in Europe: analysis of 230 cases accrued by the registry of the European Confederation of Medical Mycology (ECMM) Working Group on Zygomycosis between 2005 and 2007. Clin Microbiol Infect 2011; 17: 1859-67.

9. Kontoyiannis DP, Yang H, Song J, Kelkar SS, Yang X, Azie N, et al. Prevalence clinical and economic burden of mucormycosis-related hospitalizations in the United States: a retrospective study. BMC Infect Dis 2016; 16: 730. 
10. Pongas GN, Lewis RE, Samonis G, Kontoyiannis DP. Voriconazole-associated zygomycosis: a significant consequence of evolving antifungal prophylaxis and immunosuppression practices? Clin Microbiol Infect 2009; 15(Suppl5): 93-7.

11. Kontoyiannis DP, Lionakis MS, Lewis RE, Chamilos G, Healy M, Perego C, et al. Zygomycosis in a tertiary-care cancer center in the era of Aspergillus-active antifungal therapy: a case-control observational study of 27 recent cases. J Infect Dis 2005; 191: 1350-60.

12. Trifilio S, Singhal S, Williams S, Frankfurt O, Gordon L, Evens A, et al. Breakthrough fungal infections after allogeneic hematopoietic stem cell transplantation in patients on prophylactic voriconazole. Bone Marrow Transplant 2007; 40: 451-6.

13. Auberger J, Lass-Flörl C, Aigner M, Clausen J, Gastl G, Nachbaur D. Invasive fungal breakthrough infections, fungal colonization and emergence of resistant strains in high-risk patients receiving antifungal prophylaxis with posaconazole: real-life data from a single-centre institutional retrospective observational study. J Antimicrob Chemother 2012; 67: 2268-73.

14. De Pauw B, Walsh TJ, Donnelly JP, Stevens DA, Edwards JE, Calandra T, et al.; European Organization for Research and Treatment of Cancer/Invasive Fungal Infections Cooperative Group; National Institute of Allergy and Infectious Diseases Mycoses Study Group (EORTC/MSG) Consensus Group. Revised definitions of invasive fungal disease from the European Organization for Research and Treatment of Cancer/Invasive Fungal Infections Cooperative Group and the National Institute of Allergy and Infectious Diseases Mycoses Study Group (EORTC/MSG) Consensus Group. Clin Infect Dis 2008; 46: 1813-21.

15. Roden MM, Zaoutis TE, Buchanan WL, Knudsen TA, Sarkisova TA, Schaufele RL, et al. Epidemiology and outcome of zygomycosis: a review of 929 reported cases. Clin Infect Dis 2005; 41: 634-53.

16. Sangoi AR, Rogers WM, Longacre TA, Montoya JG, Baron EJ, Banaei N. Challenges and pitfalls of morphologic identification of fungal infections in histologic and cytologic specimens: a ten-year retrospective review at a single institution. Am J Clin Pathol 2009; 131: 364-75.

17. Hosseini SM, Borghei P. Rhinocerebral mucormycosis: pathways of spread. Eur Arch Otorhinolaryngol 2005; 262: 932-8.

18. Butugan O, Sanchez TG, Gonçalez F, Venosa AR, Miniti A. Rhinocerebral mucormycosis: predisposing factors, diagnosis, therapy, complications and survival. Rev Laryngol Otol Rhinol (Bord) 1996; 117: 53-5.

19. Lelievre L, Garcia-Hermoso D, Abdoul H, Hivelin M, Chouaki T, Toubas D et al.; and the French Mycosis Study Group. Posttraumatic mucormycosis: a nationwide study in France and review of the literature. Medicine (Baltimore) 2014; 93: 395-404.

20. Skiada A, Rigopoulos D, Larios G, Petrikkos G, Katsambas A. Global epidemiology of cutaneous zygomycosis. Clin Dermatol 2012; 30: 628-32.

21. Neblett Fanfair R, Benedict K, Bos J, Bennett SD, Lo YC, Adebanjo T, et al. Necrotizing cutaneous mucormycosis after a tornado in Joplin, Missouri, in 2011. N Engl J Med 2012; 367: 2214-25.

22. Kennedy KJ, Daveson K, Slavin MA, van Hal SJ, Sorrell TC, Lee A, et al.; Australia and New Zealand Mycoses Interest Group of the Australasian Society for
Infectious Diseases. Mucormycosis in Australia: contemporary epidemiology and outcomes. Clin Microbiol Infect 2016; 22: 775-81.

23. Pagano L, Offidani M, Fianchi L, Nosari A, Candoni A, Picardi M, et al.; GIMEMA (Gruppo Italiano Malattie EMatologiche dell'Adulto) Infection Program. Mucormycosis in hematologic patients. Haematologica 2004; 89: 207-14.

24. Lanternier F, Dannaoui E, Morizot G, Elie C, Garcia-Hermoso D, Huerre M, et al.; French Mycosis Study Group. A global analysis of mucormycosis in France: the RetroZygo Study (2005-2007). Clin Infect Dis 2012; 54(Suppl1): S35-43.

25. Chakrabarti A, Das A, Mandal J, Shivaprakash MR, George VK, Tarai B et al. The rising trend of invasive zygomycosis in patients with uncontrolled diabetes mellitus. Med Mycol 2006; 44: 335-42.

26. Kursun E, Turunc T, Demiroglu YZ, Alışkan HE, Arslan AH. Evaluation of 28 cases of mucormycosis. Mycoses 2015; 58: 82-7.

27. Arda B, Erdem A, Sipahi OR, Işıkgöz Taşbakan M, Pullukçu H, Taşbakan MS, et al. Mucormycosis: Retrospective Evaluation of 12 Cases. Mikrobiyol Bul 2011; 45: 504-11.

28. Jeong W, Keighley C, Wolfe R, Lee WL, Slavin MA, Kong DCM, et al. The epidemiology and clinical manifestations of mucormycosis: a systematic review and meta-analysis of case reports. Clin Microbiol Infect 2019; 25: 26-34.

29. Bhansali A, Bhadada S, Sharma A, Suresh V, Gupta A, Singh P, et al Presentation and outcome of rhino-orbital-cerebral mucormycosis in patients with diabetes. Postgrad Med J 2004;80:670-4.

30. El Zein S, El-Sheikh J, Zakhem A, Ibrahim D, Bazarbachi A, Kanj SS Mucormycosis in hospitalized patients at a ter-tiary care center in Lebanon: a case series. Infection 2018; 46: 811-21.

31. Deboni MC, Pozzani VR, Lisboa T, Hiraki K, Viplich R, Naclério-Homem MG. Mu-cormycosis in an immunocompetent patient: Follow-up of 1 year after treatment. Acta Otolaryngol 2006; 126: 993-6.

32. McDonogh M, Human P, Odendaal W. Mucorsinusitis in diabetes. S Afr Med J 1985; 67: 78 .

33. Shi BY, Lan L, Guo H, Tan YF. Concomitant diabetic ketoacidosis and rhinocerebral mucormycosis: report of a case. Chin Med J 2004; 117: 1113-5.

34. Lass-Flörl C. Zygomycosis: conventional laboratory diagnosis. Clin microbiol Infect 2009; 15(Suppl5): 60-5.

35. Chamilos G, Lewis RE, Kontoyiannis DP. Delaying amphotericin B-based frontline therapy significantly increases mortality among patients with hematologic malignancy who have zygomycosis. Clin Infect Dis 2008; 47: 5039.

36. Schlemmer F, Lagrange-Xélot M, Lacroix C, de La Tour R, Socie G, Molina JM. Breakthrough Rhizopus infection on posaconazole prophylaxis following allogeneic stem cell transplantation. Bone Marrow Transplant 2008; 42: 5512.

37. Kishel JJ, Sivik J. Breakthrough invasive fungal infection in an immunocompromised host while on posaconazole prophylaxis: an omission in patient counseling and follow-up. J Oncol Pharm Pract 2008; 14: 189-93.

38. Cornely OA, Vehreschild JJ, Rüping MJ. Current experience in treating invasive zygomycosis with Posaconazole. Clin Microbiol Infect 2009; 15: 77-81. 